\title{
Policies and Practices of Family Friendliness. Time and Employment Relations in Knowledge Work
}

\section{Tove Håpnes}

Senior Research Scientist, SINTEF Technology and Society, Trondheim, Norway

\section{Bente Rasmussen}

Professor, Department of sociology and political science, Norwegian University of Science and Technology (NTNU), Trondheim, Norway

\begin{abstract}
In Nonway an ideology of gender equality and the universal welfare state has created generous leave arrangements for parents, both mothers and fathers, to make the combination of work and family possible. To recruit competent women and men, knowledge work organisations have to accommodate to working hours that are compatible with the responsibility for a family. In the knowledge economy in Nonway we therefore find women and men with higher education trying to act out the ideals of gender equality at work and at home. In this paper we explore how family-friendly policies in knowledge work organisations result in family-friendly practices. We do this by analysing two R\&D departments belonging to large Nonwegian companies in the international market. Both had policies of gender equality and family friendly working time arrangements and career opportunities for women with reduced hours. We show how different employment relations and forms of organisation influenced the work and time practices of the research scientists. Using the concept of social contracts in employment and a relational concept of time, we found that it was more difficult to realise the reduced hours in the organisation that took responsibility for the career and welfare of their employees in a long-term perspective because of the mutual trust and obligations in this relationship. The women in the organisation with more transactional relations where their employment was dependent upon the market and their short-term economic performance, were able to use their accounting system to reduce their hours. The young fathers in the same organisation who were not yet established as experts, could not use the accounting system to limit their hours like the senior women. They needed to work long hours on scientific publications to qualify as researchers to secure their employment.
\end{abstract}

\section{KEY WORDS}

Employment relations / modern fathers / knowledge work / relational time / social contracts / work-life balance / gender equality.

\section{Introduction}

he knowledge economy is a fast growing sector of the economy and an important source of work and employment for young people entering the labour market in Norway. It is also attractive, characterised by flexibility and high levels of autonomy for the workers making it possible to combine work with care for children (Hyman et al.

Bente Rasmussen, Institutt for sosiologi og statsvitenskap, NTNU, N-7491 Trondheim, Norway. E-mail: bente.rasmussen@svt.ntnu.no. 
2005; Berg et al. 2003). Flexible organisations in the knowledge economy are, however, also organisations where people often work long hours, experiencing time pressure and therefore problems with the balance of time spent between work and family life (Guillaume \& Pochic 2009; Watts 2009; van der Lippe 2008; Callan 2007; Kvande \& Rasmussen 2007; Perrons et al. 2007). To ease the conflict between home and work, family friendly policies have been introduced in many organisations. Studies find, however, that even when policies of reduced hours are available, they are often not used (Gregory and Milner 2009; Hochschild 1997). The gendered perceptions of policy use defining reduced hours as the 'mommy-track' and the negative career consequences of not confirming to the model of infinite availability (Watts 2009), construct important barriers to utilise family friendly measures, leaving workers to choose either family-friendliness or careers (Halrynjo \& Lyng 2009; Halrynjo 2007; Callon 2007; McDonald et al. 2005; Epstein et al. 2004).

Norway has a policy of gender equality that has resulted in a very high participation of working women combined with a high fertility rate. Women's way into the labour market has been through part-time employment in services, mainly in the welfare state services (Skrede 1986). The strong ideology of gender equality and the universal welfare state has created generous leave arrangements for parents, both mothers and fathers, to make the combination of work and family possible (Brandth \& Kvande 2001). The ideology of gender equality in Norway entails that women and men should be both providers and carers for children. An important measure in this regard is men's quota of the parental leave that was recently increased to 12 weeks.

As a result of these policies Norway has seen a steady increase in full-time employment among women, including mothers with small children, and a decrease in the hours worked among men and especially among fathers of young children, so that men's and women's working hours are now approaching each other (Kitterød 2007a). Women with higher education has the highest rate of full time employment and couples where both have higher education, work the longest hours (Kitterød 2007b).

Day-care for children is publicly provided in Norway, and very few families use paid help in their homes either for child-care or cleaning, although the number of households who do this, has risen slightly the last 10 years (Kitterød 2009). The cultural norm is that the families should do their housework themselves, and men and women are therefore expected to share child-care and household tasks. With increased working hours of mothers, the amount of work in the households has decreased markedly, mainly because women do less housework. Men have increased their contribution to work in the household by using more time to care for their children (Kitterød 2002).

Today we find more women than men in higher education, and young people expect to have equal opportunities for careers. To recruit competent women and men, knowledge work organisations therefore have to accommodate to working hours that are compatible with the responsibility for a family, and family friendly policies are seen as means to attract women and attain gender equality in working life. In the knowledge economy in Norway we therefore find women and men with higher education trying to act out the ideals of gender equality at work and at home (Aarseth 2007).

A central challenge for working parents is organising their working time around the needs of their children without risking to be stigmatised as not serious workers (Halrynjo 2007; Epstein et al. 2004). Here time is understood as containing meaning (Roberts 2008), a relational concept that moves the attention from the number of hours spent working or caring for children, to the meaning of the activity, i.e. to how time symbolise the value and 
commitment to the activity, like being a serious worker committed to the organisation as opposed to a parent who put priority to her or his family's needs.

In this paper we will explore if and how family-friendly policies in knowledge work organisations result in family-friendly practices. We will do this by analysing two R\&D departments, Chemical Lab and Software, belonging to two large, well-established and prestigious Norwegian companies in the international market. Both organisations had policies of gender equality and family friendly working time arrangements and both offered professional careers for women with reduced hours. We will show how different employment relations and forms of organisation influenced the work and time practices of the research scientists. Before we present our method and findings, we will introduce the two theoretical debates that have informed our analysis; the flexibilisation of organisation and employment relations and a relational concept of time.

\section{Flexibility and changing employment relations}

The knowledge economy is characterised by flexible and so-called post-bureaucratic forms of work organisation (Alvesson 2004) as well as more flexible and short-term employment relations. Cappelli (1999) argues that the erosion of long-term permanent employment relations is the result of a drive for innovation in competitive markets for knowledge intensive products and services, pressuring the organisations to access cutting edge knowledge. Instead of taking responsibility for developing the qualifications in the firm, employers increasingly use the market to buy workers with the qualifications that they need, offering them opportunities, but no long-term relations. According to Cappelli, this 'new deal' at work no longer offer the workers life-long 'marriage' to their employees, but temporary relations like the serial monogamy of modern family relations: we're only together as long as we find the other interesting and useful. In return for their short-term employment, the firms offer challenging tasks and professional development, i.e. an interesting $\mathrm{CV}$, qualifying the workers for careers elsewhere. In these employment relations the workers are left with the responsibility for their own employability (Cappelli 1999; Kunda \& Ailon-Souday 2004; Sennett 1998).

The development of a 'new deal', origins in the US labour market. Nordic and Norwegian labour relations (Ervasti et al. 2008) are different from American. The labour laws and regulations in Norway restrict the use of temporary employment contracts to tasks that are not part of the ordinary business of the organisation, or, to fill in for (named) persons who are on leave (sick-leave, parental leave etc.). However, changes in employment relations are not limited to changes in formal contracts, but may also be found in the practices of employment relations, changing the social contract between the workers and the organisation (Rousseau 1995). The social contract is the unwritten or implicit contract as it is understood by the employees, concerning the mutual expectations between employer and employees as to the duration of the relation and the efforts, results and rewards that they may expect.

Rousseau (1995) distinguishes between two ideal types of employment relations: the relational and the transactional contract. The relational contract is as an open-ended and broad relation. The ideal type is the life-long employment relation where the parties invest much over a long period to develop and sustain the relation, creating internal careers, commitment and interdependence over time, like in traditional bureaucratic 
organisations. The relational contract is therefore long-term and based on trust by both parties concerning their reciprocal obligations. The relational contract therefore has a lot in common with family relations; we're there for each other and in it for the long haul. Transactional contracts are market relations based on a specific exchange which takes place over a finite period as an economic transaction, and the reward is directly related to the effort. Market relations are based on distrust (Adler 2001) and the organisation do not invest in the relation in a longer term perspective, but uses the qualifications and competences of the employees as long as they are economically profitable. Cappelli's (1997) 'new deal' is a more transactional contract when the workers' are made responsible for their employability and their employment is dependent upon their short-time economic value for the organisation. In a long-term relation where rewards may be expected in the future, it makes sense to invest extra efforts and suppress personal needs for the benefit of the company's interest. In short-term transactional relations rewards must follow effort. The different time-perspectives of the social contracts in the different employment relations therefore give meaning to the relation between employee and organisation, regulating their efforts in relation to rewards.

Following this argument, we would expect employers practising relational contracts to allow their employees to have periods in their lives when their work effort varies, like when they have young children. We might, however, also expect employees to be willing to put in extra effort when this is needed for their employer, because they will be rewarded for this in the future (Hochschild 1997). A long-term employment relation may therefore offer family friendly measures to make it easier to find a work-life balance for parents with young children (see Watts 2009), but not necessarily to use these measures to reduce their time at work. The insecurity of a short-term transactional relation might increase the pressure to work long hours because the employees would be personally responsible to meet profit and production targets (Sennett 1998), but it might also lead to resistance to work long hours unless they were well paid. The time perspectives of the employment relations may therefore influence time practices at work in different and sometimes contradictory ways.

In a gender perspective the time-norms and cultures of the organisations matter when women, or men, want to limit their work-hours to make time for children. In a qualitative study of women civil engineers in the UK construction industry, Watts (2009) found that it was difficult for the women to break the long-hours culture that dominated the industry if they were to be taken seriously and have a career in the industry (see also Halrynjo 2007; Halrynjo \& Lyng 2009; Epstein et al. 2004). They experienced a direct pressure to confirm to a norm of always being available that had become more pronounced in the current global competitive environment. Only the most senior who had been with the employer for a long time, managed to establish some flexible working to accommodate for family life (Watts 2009).

\section{A relational concept of time}

The focus in the debate about knowledge work, long hours and family obligations, has tended towards a focus on the individual worker and her choices of how to 'balance' time for work and family. In this debate time is usually understood as a natural entity that can be measured and divided, and 'balanced', between work and family, and not as a relation of power in gendered organisations (Sabelis et al. 2008). When time is 
understood as 'clock-time' in line with the employment practices in terms of the basic time $=$ money equation, the quantity of time is in focus, but not the quality (Roberts 2008: 432). Roberts views time as a 'container of meaning' when she studies how individuals allocate time to different activities, using temporal customisation to regulate the time spent on their job, making time for activities that were meaningful for them (Roberts 2008). Thereby they were able to have 'enough time for meaningful things' (Reisch 2001: 374). Like the time perspective of the employment relations give meaning to the time practices of the employees, we argue that their time practices give meaning to their relations, at home and at work. In a moral economy of time, 'family time' and 'quality time' have become the symbols of a proper family life (Brannon 2005: 117).

European studies show greater differences in actual working hours than in preferred hours, indicating that there are cultural norms for what is seen as suitable working hours for women. Many Norwegian women who answer that they would prefer reduced hours, do not reduce their hours even if they have the opportunity. This indicates that preferred hours should be understood as ideals relating to the norms of parenthood, where time spent with children is a measure of good parenthood (Ellingsæter 2009). These norms have changed for mothers and fathers in Norway. Women in Norway are now expected to work as well as care for their children, and men are also expected to care for their children. Changing norms are the result of increased gender equality and the economic necessity for both parents to work in order to provide for a family. The provisions for parental leave make it possible for both parents to realise the ideal of dual earners and carers (Brandth and Kvande 2009).

The good mother is symbolised through her use of time with her children, and the norm of the good mother in Norway is a woman working part-time. In Norway a 'good mother' should work less than full-time and a good father should not work long hours (Ellingsæter 2009; Johansen 2007). Women working full-time therefore have to compensate for their hours at work to be good mothers and are the ones who use most time on activities with their children (Kitterød 2002). Thus time use is embedded in social relations and symbolic interpretations.

The time practices and their symbolic meanings are not only dependent upon national culture and political contexts, but also upon organisational cultures and norms (Callan 2007). To work long hours have in many work cultures come to be the symbol of loyalty and commitment to the organisation (Hochschild 1997) and being a serious worker interested in a career (Epstein et al. 2004; Halrynjo 2007; Watts 2009). Following the debate of Gregory and Milner (2009) and moving beyond the individual women, we are interested in how gendered time practices are constructed in work organisations. We thus combine the traditional interest in research on time use with an interest in how the organisation and culture of work is developed and maintained through management practices and workers' strategies. We are interested in how different work organisations and employment relations construct and consolidate different time practices. To analyse these time practices we will use the concept of social contracts and a relational concept of time.

\section{Method}

To analyse this we use data from a qualitative study of the organisation of work and employment relations in knowledge work. The study comprised four case studies of or- 
ganisations of knowledge work (Håpnes \& Rasmussen 2008). Analysing the data we found that two of our cases, both in male dominated areas of work, were very interesting because both had an active policy of recruiting women and family friendly policies like company sponsored day care and reduced hours for parents. They allowed flexible working with a fixed work period between 0900 and 1500 hrs. Neither were typical 'greedy' knowledge organisations with very long hours. On the contrary, these were firms who strived to offer good and attractive employment for experts in science and technology. Both firms also promoted women who worked reduced hours to senior and management positions. There were however, also interesting differences between the two cases as to whether the women (and men) were able to realise their (reduced) hours. (Since the modern fathers did not reduce their hours, but were unable to keep to their normal hours).

For this paper we have therefore chosen to analyse the time practices of parents in the two organisations; a department for ICT-research, Software, belonging to a large international research institution, and a research department, Chemical Lab, part of a large international industrial corporation.

Chemical Lab employed 30 people under a male manager of around 45 years old, and 50 percent of the researchers and laboratory personnel were women. The age of the workers were between 28 and 50 plus, most of them between 30 and 40 . Chemical Lab did advanced research into chemical processes. The tests could last for days, weeks or months and meant intense collaboration in teams of different types of workers. In Chemical Lab we interviewed the head of the department, five female and three male scientists and two female laboratory engineers. Our analysis here is mainly based on the in-depth interviews with the five female scientists. Four of them had children under school age or in lower primary school. One of the female scientists had management responsibilities and four were project managers, and all but one worked mainly in the laboratories testing processes with advanced equipment.

Software employed four women and 26 men. Software had an image of an old fashioned ICT-environment dominated by graduate engineers working on software engineering for the transport and health sector, on systems architecture and systems development processes. The head of department was a woman in her 40ies with small children in an 80 percent position. The other women in the department were around the same age, and all had school children. In Software we also found a group of young men with small children who struggled to make time for projects, publishing and care for their children. In Software we interviewed the four female scientists, and eight of their male colleagues, as well as the head of the department. In our analysis here, we make use of the interviews with the four women and with four younger men who were members of a research group working on software development and their group manager (also male). We followed up the interviews with the young men with a focus group, a strategy that offered more dialogue-based data with lot of reflection about their work, time practices and position in the department. We use some of these open dialogues in our analysis.

We followed the departments over one year and collected data by using field observations and qualitative in-depth interviews with a strategic sample of workers covering different positions, experience and expertise. The field observations gave us good insight into different research teams and their work practices, the departments' area of research, and organisational and cultural characteristics. We participated in internal meetings and seminars, took part in coffee breaks and informal discussions and observed some demonstration programmes and laboratory tests to obtain better insight into the work processes. Through 
the observations we were able to place more specific questions in the following interviews. Analytically, we use the observation data as a complementary resource to the interviews.

We made field notes during our observations and all interviews were digitally recorded and transcribed. As a part of the analytical process we have constructed three categories which express important differences in how the employees formed their family friendly reduces hours in practice. The first category is the fire fighters that we found in the Chemical lab.

The second is the balancing actors that we found in Software, and finally, in the same department we found the modern fathers among the young male researchers in software development. The three categories are based on what we found to be "typical" practices inside the specific R\&D contexts we studied. They express how different groups of research scientists with young children developed different working time patterns shaped by their collective work practices and the organisation of work that structured these. By using the label fire fighters in Chemical lab, we wanted to capture the female researchers' readiness to leave home even at night, to take care of their laboratory rigs in case of serious trouble. We have called the female senior scientists in Software balancing actors. This label emerged through their stories of how they managed to balance between their responsibilities to their research projects, customer demands, their colleagues and the (changing) needs of their children. In Software we found two different generations of men, men between 40 and 60 who had been in the organisation for a long time and young men in their 30ies. In the last group of young men we found the modern fathers. This label indicates that they wanted both a professional career and to take care of their children, like the feminists of the 1970ies. The modern fathers prioritised their children and families like the women in Software, but differed in important aspects. We use the categories as a kind of typology to show the complexity in how the time practice at work became formed by many and partly contradictory demands formed by employment relations, organisational structures as well as family life.

In this paper we want to explore the differences in the time practices of combining responsibilities for work and family between the women scientists in the two organisations, but also between the senior women and the young men in Software. We want to understand how and why the different groups developed time practices and whether they were able to limit their work effort and realise their reduced hours, and the generalisation of our findings is therefore theoretical, contributing to the literature that try to understand how work and careers can be combined with family responsibility in work organisations in an institutional context of gender equality.

\section{The fire fighters}

Fire fighter is a gendered concept. It alludes to a male work culture associated with being called out, day or night, to rescue life and property in case of fires. This willingness to be on call in case their tests were in trouble, was also characteristic of the work in the laboratories. What distinguished the women in Chemical Lab from their male colleagues was that the women worked reduced hours, $80-90$ percent of the normal work week, to accommodate to the needs of their children. For the women in Chemical Lab working reduced hours was more problematic than it might seem because their tasks were specialised, and each were in their specialities indispensable for the firm: 
'I do the same as before and get paid less. That is the result, because nobody else does my tasks for me when I'm not there. If I'm not starting the test process, or take it off or look at the results, then nobody does.' (Cathy).

Being assigned to special projects, their work load often remained the same when they reduced their hours. Either they had to spread the tests over a longer period, or work harder and longer than their hours. When other departments were waiting for the results to solve their problems, using longer time was not an option:

'I have worked $90 \%$ for a long time, but in practice I do not work $90 \%$, but more like a 100. But it gives flexibility and a feeling that I do not have to hurry all the time. If I had worked full time I would also have worked more. I note my extra hours in my desk drawer, and they grow and grow.' (Christine).

Their shortened hours gave them the opportunity to buy extra flexibility and a legitimate boundary to work, signalling that they were not only professional women with careers, but also 'good mothers' making room for time with their children (Brannon 2005; Ellingsæter 2009; Johansen 2007). In practice, however, the negotiation of a certain buffer in the form of 10-20 percent reduction in hours, did not reduce their hours below the normal work week of 37,5 hours. It worked, however, as a symbol so that they could legitimately limit their overall hours, like Roberts found in her study of the temporal customisation of the 'work-busy' (Roberts 2008: 442).

They were not compensated for extra hours because they were already paid well as experts. Clare, who worked full-time, was also the one who worked the longest hours. She managed a large inter-departmental project involving many workers in different geographical locations. She described her days:

'Normally I work (from 8 ) to 4.30 or 5 in the afternoon. Then I work longer one or two days of the week... There's a lot to do and maybe I get involved in more than I should... And then there is always something you have to see to -things that you haven't planned. And then you leave your door open for everybody to come in. Everything that I planned to do is often moved to the evening. Not everything, but a lot.' (Clare)

Clare combined working in the evenings with being with her family. She placed her laptop in her lap in the sofa in front of the TV so that she was accessible and could engage in discussions with her family. A driving force for Clare was her strong engagement in her job and the large important project she was heading.

Those who were responsible for the long process tests, could not work normal days when the tests ran. They would come in at night and on weekends to take samples and check if the tests ran as they should. Chris, a technician on Lab-duty after work hours, gave a good description of lab-life: "We often have to get out on week-ends...we take samples, .. do the morning management on all the rigs. It's like dairy management!” The research scientists who were not on Lab-duty, would also have to come in if their tests were in trouble. It all depended on what happened in the lab:

'Last night I sat by my bedside ... and I heard the alarm on my cell phone. First I thought it was a message, but no... We talked for a while first to see whether I had to come down 
or they could manage, but I decided soon that I had to go. I understood that several installations were in trouble. So I was not alone here last night.' (Christine)

The women in Chemical Lab who tried to reduce their working hours were therefore caught up in challenging and exciting jobs and an organisation that was dependent upon their results. The firm gave their employees opportunities for development in their field and careers as well as high wages in return for their responsibility, but did not reorganise to facilitate shorter hours. The regulation of the responsibilities at work and at home was left to the individual workers:

'As a senior engineer I have an extra week vacation... but after the first month of the year I have earned that, in a manner of speaking. But you're not to work more than you like here. And the managers are very good at looking after us: "You mustn't work so much". But, it's not so easy... you've got to manage to leave things undone, saying "I cannot manage this". I think that in the end it comes down to the kind of person you are.' (Clare)

They were, however, very satisfied with their jobs in Chemical Lab. Their work was important for the firm and for the national economy. The company invested in them and their careers, and was concerned about their welfare. The granting of shorter hours was therefore experienced as a sign that the organisation cared about their welfare because they were important and indispensable workers. In return for the concern about their welfare in the form granting them reduced hours, they acted responsibly and worked hard. What the company invested in them and offered in terms of opportunities and careers, counted for more than the extra hours worked. They looked upon themselves as the chosen few who were lucky to contribute in an important field of work and in a well-known and respected company. Here we see the 'old model' of a bureaucratic career with an emphasis on self-sacrifice, a calling and a dedication to serve (the company, the nation) like Guillaume and Pochic (2009: 21) found among the engineers in a public utility company in France.

The employment practices of Chemical Lab demonstrated their relational contract; the company took care of the workers in a life-long perspective and invested in their training and career in the company. The graduate engineers were expected to build a career alternating between staff and line positions and between different locations (see also Guillaume \& Pochic 2009). Their career perspective was therefore not primarily as experts within the research laboratory, but in the mother company, and their identification with and loyalty to the company, mirrors this.

The family friendly policy of Chemical Lab was aimed at recruiting the best research scientists and other personnel and to keep them in the company for the rest of their careers. To do this, they allowed their employees to reduce their hours when they needed to meet care responsibilities. The long-term perspective and investment in the employees was also visible when the career trajectories involved placement in production plants abroad or at home, and the company offered work opportunities for spouses within the company.

Their family friendly policy was, however, gender neutral rather than women friendly since besides offering day-care for children, they let the workers reduce their hours when needed without reducing their work load correspondingly. This resulted in a masculine engineering culture where the women adapted to a culture where they 'did 
what it took' and answered to the needs of unpredictable processes and disasters in the laboratory (Watts 2009). In this way the responsibility of combining a demanding job and the needs of small children were left to the individual women to manage.

\title{
Female balancing actors
}

The women in Software worked as research scientists and had been established in their field for 10-15 years. Three out of five had children in primary school. How did they experience managing their jobs and their families with reduced hours?

'Being a mother and working here as a researcher, is a very good combination. I can bring my work home, I can work weekends if I want to, which I'd rather not do, but if I have to. I can leave early, or come late if I want to. As long as I take care of my tasks in the projects and don't make it difficult for my colleagues...' (Sunniva)

The flexible hours of work in a research institute made it possible to move tasks in time and geographical location and therefore easy to combine work and care of children. Like in Chemical Lab, the working mothers needed more flexibility than their flexitime offered, and three of the women in Software had reduced their hours. While the women in Chemical Lab worked 90 percent, the women in Software had tried different solutions:

\begin{abstract}
'After my second child was born, I have worked 80 percent. You can always discuss if that is right, but I prioritise working less. I have reasoned that it is not in my interest to work myself to the bone. (...) I take it out in slightly shorter days, or I take extra vacations when the children have breaks at school. (...) I work full time in between, but I register the hours that I work so that I can compensate by taking time off. I seldom work from home.' (Sarah)
\end{abstract}

Sarah was the mother of three and found that working $80 \%$ was not a problem in getting the work done. After she took over managing her research group, it had become more difficult to work shorter days. Instead she collected the extra hours and took days off extending a weekend or a vacation to fit the schedule of the schools, thereby balancing the needs between her job and her children. Sunniva also had an 80 percent position when we interviewed her, and she had tried different models:

'When I started here, I worked 60 percent. Afterwards I had periods of 65 and 70 percent, and now I work 80. It has been uncomplicated, except when I worked 60 and 65 percent. Working such short hours I couldn't manage to take on many tasks. (...). When I work 80 percent, I mostly work around 90, but I extend my summer vacation. It is perfect, really fantastic. When I worked shorter hours, it was a problem because I didn't have the time to take part in exciting projects.'

Sandra was head of the department. Officially she worked 80 percent when we interviewed her (in practice her days were longer). For her it was a political statement to demonstrate that it was possible to have a management position and work reduced 
hours. As a manager she was responsible for managing her job within her hours, or, working reduced hours, to register her extra hours up till 100 percent.

All the women with reduced hours worked longer, and often 100 percent during the week, but they reduced their hours by taking days off in school breaks. In this way they used temporal customisation as a route to work-life balance (Roberts 2008). They developed personalised schedules fitting their responsibilities at work and at home, changing these when their needs changed, as when Sarah took on management responsibilities for her group.

How did they manage the balancing acts between demanding and challenging research and parental responsibilities? The answer can be found in their work practices and in the time accounting system in the research institution.

\section{Work practices}

Working as a contract researcher demanded a lot of time writing applications, negotiating contracts, contact with users of the research and collaborating partners, and data collection, much of which implied travelling. Their jobs demanded extra efforts to deliver good results within deadlines:

'The people who work here are very competent, and they want to deliver good quality work. The results are driven by their pride and ambitions. They want to do a good job, and therefore they put in the hours that's necessary, which means that at times we work a lot; an application must be produced, a report finished.' (Sunniva)

The researchers in Software liked their work; it was meaningful, and the department a friendly and collaborative workplace. The balancing actors were established in their fields with a name and important networks, but they were not willing to sacrifice everything for their research and the department. As expert scientists they were responsible for contracting research projects, and their employment was dependent upon the market for research in their field. They knew their market and were able to plan the projects taking into account the needs of the customers and what they were willing to pay. Working in ICT, their competence was cutting edge, and they could ask a high price in contracted projects to finance their professional development. Their experience and knowledge of their field and the market, therefore enabled them to finance their projects adequately and regulate and limit the amount of work they put into the projects.

\section{Time accounting system}

The mother institution of Software used weekly timesheets where the researchers registered the hours that they worked on paid projects and other activities. This time keeping was not popular among the researchers, but it documented their work. When they had worked the required and contracted billable hours, they could take time off. The timesheets made their efforts visible to themselves, their group manager and the head of department. In contrast to the workers in Chemical Lab who needed their manager's OK to take time off for extra hours worked, the researchers in Software could take time 
off as long as they managed their projects and the collaboration with their colleagues. Being accomplished entrepreneurs in the market for IT-research, they were able to control their work effort in the projects and deliver good results, using the time accounting system.

The transactional system of accounting made it possible for the balancing actors to reduce and customise the hours they worked in line with the reduction in their formal position. The bureaucratic system of time registration and accounting that documented their efforts and the economic results of their work, was also a protection of the employees and legitimated their limitation of hours worked (Courpasson 2000). The transactional relation therefore counteracted a culture of presenteeism where long hours worked could act as proxies for being a serious worker (Epstein et al. 2004) or excellence and commitment (Watts 2009: 54). Instead it promoted a culture of performance with a focus on results, making flexibility possible for the researchers, a strategy that Guillaume \& Pochic (2009: 31) has characterised as a new and innovative strategy for women to manage both a career and family life.

The accounting system in itself is, however, no guarantee for managing the time to care for children, as we will see in the next section when we turn to the modern fathers in Software.

\section{The modern fathers}

The young male researchers in Software were not specialised and well-established like the balancing actors (only one had a $\mathrm{PhD}$ ), and all worked full time. They found the experience of being fathers of young children and working full time exhausting, but their families depended on their income because their partners were either students looking for jobs or in an insecure position in the labour market. Their style of work had changed after becoming fathers. They were more structured because they had to leave work at four o'clock to pick up their children from day-care. Two of them also delivered their kids in the morning; one because the day-care centre was close to his work, the other because his partner's job did not allow her to schedule her day around the day-care centre's hours. This had an impact on their days, as Simon told us:

\footnotetext{
'He (the son) shouldn't spend more than seven hours in day-care, and because I work very close, I drop him off and pick him up, and as a result I can't work more than seven hours. So, I try to fit in an hour or two in the evening. It's exhausting feeling guilty all the time, and having too much to do is exhausting as well. On the other hand, it is very flexible, so I am able to adjust my day. We are personally responsible for what we do. Nobody is cracking the whip to get you going, you're doing it yourself.'
}

The work situation of the young men was different from that of the women in the department who were already established experts. To secure their future employment in the research organisation, they needed to qualify by acquiring a $\mathrm{PhD}$. Their opportunity to qualify was good because they belonged to a research group where great emphasis was placed on scientific publication. Their group manager was part of a professional network of leading researchers in their field that offered the group the chance to publish. This was exciting and very attractive. The success of the young 
researchers was, however, dependent upon their group leader, and the way he worked set the standard for the entire group. He described what he believed it took to become a good researcher:

'If you are going to succeed in research, you can't really think it can be done between eight and four. If you prefer to work from the time the kids go to bed until midnight, I think that is fine. (...) I probably work about ten hours a day on average, maybe more. I'm here between eight thirty and four thirty. Then I work from home maybe two to three hours every night, and the same on weekends.' (Svein, group leader)

The young men in the software group structured their time during the day to finish project activities and communicate with colleagues and customers. Then, they tried as best they could to find the time at night to write papers and articles. This put a lot of pressure on them:

'Research requires you to think more long-term and to balance reading and publishing quite heavy tasks - with everyday activities, when you are constantly interrupted. It has been really exhausting this last year. I can see that my research is suffering, and that is my problem. You have this pressure from management to publish, and it can be quite frustrating. You feel like you can't do a good enough job'. (Sigurd).

They thus found their job exciting, but also tiring, and they felt guilty, not primarily in relation to their families, but because of their obligations to their group leader. They felt that they did not live up to his standards of a good researcher. Sigurd and Simon touched on this in the focus group discussion:

Sigurd: 'I don't feel as guilty with my family, because they get top priority. That's just the way it has to be. If my wife is away, I have to take care of the kids. (...). But I feel a lot of pressure if I have the kids for a couple of nights and have to do all the bedtime stuff with them, then, I feel really stressed around nine-ten at night, and think: Shit, I should have finished that paper.'

Simon: 'So, you work a lot at night then, do you?'

Sigurd: 'Yes, either I'm working or I suddenly feel really guilty and I think to myself that this isn't how I want it to be. Then I sit down on the sofa and think that I'm going to take some time off, but then I sit there and watch some garbage on the telly. Then I feel guilty too, for not doing some publishing work instead.'

The working situation for the young male researchers who needed a $\mathrm{PhD}$ to make a career in research, was therefore very different from that of their well-established female colleagues. Since they were not established as experts in the market for research, they were employed in the projects of the seniors. This gave them less control over their work situation and they were not able to generate slack to provide time for professional development. The transactional employment relation in Software where they were (individually) responsible for their qualifications and their employability, meant that they had to do what it took to qualify for expert positions even if it meant working long hours.

We called this group the modern fathers because they wanted to be fathers who took responsibility for their children, but also to participate fully in their jobs. Part-time 
being gendered, they did not find acceptance that they, as men, could work less to meet the demands and needs from their family. The requirement to go the extra mile to publish, meant that the group leader had little tolerance for them cutting back on their dedication to publish because they had small children. Some of them found that the routine was too much. They felt the need for a timeout and a break from the job, wanting to spend more time with their children. Stian had opted for six months paternity leave and saw this as a chance to avoid exhaustion from the pressure at work:

'I was on paternity leave from February to August last year. That was great, because I had been working in the same field for quite a while and it felt good not to be doing that anymore. (...) Now there is another one here, going on paternity leave in May, and he is going to be gone for almost the entire leave period.' (Stian)

They described paternity leave as a release because it represented a legitimate buffer from work to prioritise their family. In contrast to part-time work that is understood as a reduction in hours for mothers, long parental leave for fathers is accepted in Norwegian firms (Halrynjo 2009). At the same time, the need for longer leave indicated that they were afraid that they would not be able to work as much in the long run. The modern fathers had a great deal more daily responsibility for their children than men traditionally have had. Their partners wanted a more equal distribution of the parental leave to engage in their own education and career, acting out the ideals of gender equality as described by Aarseth (2007). The young men therefore found themselves in a situation similar to that of Scandinavian women in the 70s, who wanted to combine careers with having children at a time when there was a lack of public care, flexibility at work and acceptance for the needs of parents with small children among employers and colleagues.

It was the pressure to publish through the professional network of their group leader that structured their work practice, resulting in long hours and work in the evening to prepare scientific papers. Since this was an activity that was normally not billable, they could not use the accounting system as a boundary against work. Instead they used paternity leave. Callan (2007) found in her study that it made a difference for men whether they had to ask for flexibility and time off for family needs or whether they had a right to time off, for example by having worked extra hours. They would rather use formal rights and collect hours than being dependent upon the good will of their managers (Callan 2007: 685). Here we can see a parallel to the use of paternity leave of the modern fathers and the successful reduction of hours by the balancing actors in Software.

The time accounting system in Software made reduction in hours possible, but only if they had worked the required amount of billable hours. The necessary investment in their qualifications did not follow the transactional logic and were not billable. This was the root of the problems for the modern fathers. They were expected to work the contracted hours needed to finance the cost of their employment and deliver good quality results, but investing in their expertise became their individual responsibility, even if the organisation was dependent upon it. The accounting logic was built around an economic logic of the bottom line. In this sense the social contract in Software was an example of the transactional 'new deal' as described by Cappelli (1999). 


\section{Conclusion}

We asked whether and how the family friendly policies in Chemical lab and Software resulted in family friendly practices, i.e. if the family friendly policies gave them more time with their children without stigmatising them as not serious workers. We found that the women in Chemical Lab who reduced their hours to 80-90 percent, signalling that they wanted to work less and thereby confirming to the norms of good motherhood in Norway, were not stigmatised, but seen as serious workers and offered careers. They were, however, only partly able to realise the reduction in hours that they had negotiated. It allowed them some flexibility, but only to a certain degree to limit their availability for work. A life-long relational contract entails an acceptance of variable work effort over a life-span and implies a family friendliness that a short-term transactional contract where the duration of the employment relation is dependent upon the market in a short-term perspective, does not. The trust and mutual dependency and the reciprocal obligations of the relational contract, made the extra effort easy to give when it was needed. It was therefore difficult to limit the involvement of the employees who had reduced hours, just as it was difficult to keep within the normal work week for the ones who worked fulltime like Clare. We can understand their extra effort as an expression of their relation to the company; they trusted the organisation to take care of them and have their interest at heart as well as that of the company, and in return they were willing to go the extra mile for the company. In this sense the relational contract in Chemical Lab made the organisation 'greedy', making the employees willingly give more of their time to their employer (Coser 1974, Rasmussen 2004). The practices of the company, including the opportunities for reduced hours, reinforced the mutual trust and long-term perspective of the relational contract. Because of their long-term relationship and care for welfare of the employees, their practices are certainly family friendly in a long-term perspective. However, the extra willingness to work extra when needed that these practices induces, makes it difficult to realise family friendly practices in a short-term perspective. Compared to other Norwegian organisations working in the international market where American norms of total availability were practiced, the practices of Chemical Lab were, however, very family friendly (Kvande 2009, Børve 2007).

Like the women in Chemical Lab, the women in Software also reduced their hours and confirmed to the norms of being good mothers, without repercussions for their status and careers. Since they were established experts and their position in the market for research was secure, they were able realise this reduction. Although not on a daily basis, but taking responsibility for their projects and customers, they were able to organise time off work to accommodate to their children's schedules. These opportunities were, however, dependent upon their entrepreneurial success in the market for research since Software did not promise them life-long employment like Chemical Lab. The modern fathers in Software illustrate this. Their precarious position in the research institution without a $\mathrm{PhD}$, made it difficult for them to limit their work effort to their paid projects. They needed to qualify by scientific publishing, and their group manager offered them opportunities for this through his network and set the standard by working very long hours. This left them with a bad conscience when they did not meet their moral obligations to his (and their) aspiration for their professional development. Not taking the time to publish symbolised being a poor researcher who did not aim at a professional career. 
When the transactional logic of time-sheets in Software facilitated the reduction in hours for the balancing actors who were experts and had earned a secure position in the market, this is in line with van der Lippe (2009) who found in her survey that a short-term employment relation did not increase conflicts of work-life balance, and even decreased such conflicts for men. She found that it was the combination of the responsibility to meet deadlines and autonomy that increased feelings of time pressure, like we saw in Chemical Lab and among the young fathers in Software.

If we ask which of these organisations had the most family friendly practices, the answer is therefore not straightforward and dependent upon the time perspective we use. We have shown that it is not enough to look at the formal reduction of working time to conclude about family friendliness. When the balancing actors in Software were able to balance successfully between work and family and realise their reduced hours, this was because their secure position in the market for research in their field made this possible. This was, however, not the case for the young researchers without a $\mathrm{PhD}$ in the same organisation. They had to put in the extra hours to publish to gain such a position.

In contrast to a relational contract like we saw in Chemical Lab, a transactional contract implies a short-term 'market' relation where the results are easy to measure and reward. The timesheets of the accounting system in the research institution facilitated this in Software. If they had filled their obligations regarding billable hours, delivered the results on time and worked more than the contracted hours, the researchers could take time off like we saw in the case of the balancing actors. This was possible as long as they individually had enough hours on paid projects, thus dependent upon their position in the market for research. If they were not able to contract enough projects to finance their employment, they would have to work on acquisition to fulfil their economic obligations, or their employment would be endangered.

The young men who needed to qualify as experts to establish themselves in the market for research, were not able to limit their hours to the normal working week. Even if they fulfilled their obligations on contracted projects, they would still need to work extra hours to publish. Their employment in Software was dependent upon the senior researchers acquiring projects that needed their labour power. Software was totally dependent upon the market for research in their field; i.e. upon the researchers contracting new projects. Changes in the market had direct effect upon their employment, and the position of the young researchers was most vulnerable for market changes. In contrast, Chemical Lab belonged to a large international corporation and their projects were generated and commissioned by the corporation. They were therefore not dependent upon an external market for their projects, but developed their research in dialogue and cooperation with relevant parts of the corporation. The family friendliness of Software was therefore only for some employees and not for others, and only in a short-time perspective, but not in a long-term perspective.

Returning to the argument that long-term relational contracts would make it easier to resist pressure towards working long hours than short-term transactional contracts (Sennett 1998; Watts 2009), our analysis shows that the picture is more complicated and the relation between employment contracts and time-pressure more complex. In Chemical lab it was the value of the long-term relation with its trust and mutual dependency that made the women willingly work longer when needed. Here we see the parallel to the attraction of jobs that valued the contributions of the workers and offered them 
opportunities and recognition that Hochschild (1997) found and that could explain why the workers in her case did not use the family friendly policies.

In Software the individual research scientists were responsible for their economic contribution to the organisation and the projects to their customers, and thus also for their employment. As long as they managed to do this within the contracted hours, they were free to take time off when it suited them. The young men who were not yet experts, was under pressure to work more hours to qualify if they were to have a career in research.

To understand family friendliness in practice, we therefore need to take into account the time-perspective of the employment contracts, the position of the organisation in market and the position of the individual employees in the labour market to understand how the time practices at work are developed. The practices may vary for different groups in the same company, dependent upon their employment relation and their position in the opportunity structures inside and outside the organisation where they work. The economic situation in general and in the labour market also shape the way organisations treat their employees. In times of scarcity of labour the employers may need to offer more secure employment relations, invest more in their employees to keep them in the organisation and meet workers' demands of flexible work to balance work and family like Hyman et al. (2005) show in their study of software workers.

\section{Acknowledgement}

The project was financed by the Norwegian Research Council grant no. 156100.

\section{References}

Aarseth, H. (2007) 'Optimalisering på alle livsområder? Likestilt familieliv i ny økonomi', in Kvande, E. and Rasmussen, B. (eds.) Arbeidslivets klemmer. Bergen: Fagbokforlaget.

Adler, P. (2001) 'Market, hierarki and trust: The knowledge economy and the future of capitalism', Organization Science 12(2): 215-234.

Alvesson, M. (2004) Knowledge Work and Knowledge-Intensive Firms. New York: Oxford University Press.

Berg, P., Kalleberg, A. L. and Appelbaum, E. (2003) 'Balancing work and family: the role of high-commitment environments', Industrial Relations 42(2): 168-188.

Brandth, B. and Kvande, E. (2009) 'Norway: the making of the father's quota', in Kamerman, S. B. and Moss, P. (eds.) The Politics of Parental Leave Polices. Bristol: The Policy Press. 191-207.

Brandth, B. and Kvande, E. (2001) 'Flexible work and flexible fathers', Work, Employment and Society 15(2): 251-267.

Brannon, J. (2005) 'Time and the negotiation of work-family boundaries', Time \& Society 14(1): 113-131.

Børve, H. (2007) 'Pregnant bodies. Norwegian female employees in global working life', European Journal of Women's Studies 14(4): 311-326.

Callan, S. (2007) 'Implications of family-friendly policies for organizational culture: findings from two case studies', Work,Employment and Society 21(4): 673-691.

Cappelli, P. (1999) The New Deal at Work. Managing the Market-Driven Workforce. Boston, Mass.: Harvard Business School Press. 
Coser, L. (1974) Greedy Institutions: Patterns of undivided commitment. New York: Free Press.

Courpasson, D. (2000) Managerial strategies of domination. Power in soft bureaucracies. Organization Studies 21(1): 141-161.

Ellingsæter, A. L. (2009) Vår tids moderne tider. Oslo: Universitetsforlaget.

Epstein, C. F., Seron, C., Oglensky, B. and Sauté, R. (2004) 'Part-time work as deviance: stigmatization and its consequences', in Sacks, N. E. and Marrone, C. (eds.) Gender and Work in Today's World. Cambridge, MA: Westview Press.

Ervasti, H., Fridberg, F., Hjerm, M., Kangas, O. and Ringdal, K. (2008) 'The Nordic model', in Ervasti, H., Fridberg, T., Hjerm, M. and Ringdal, K. (eds.) Nordic Social Attitudes in a European Perspective. Cheltenham: Edward Elgar.

Gregory, A. and Milner, S. (2009) 'Editorial: Work-life balance: A matter of choice?' Gender, Work and Organization 16(1): 1-14.

Guillaume, C. and Pochic, S. (2009) 'What would you sacrifice? Access to top management and the work-life balance', Gender, Work and Organization 16(1): 14-37.

Halrynjo, S. (2009) 'Men's work-life conflict', Gender, Work \& Organization 16(1): 98-126.

Halrynjo, S. (2007) 'Alltid beredt? Arbeids- og familiedilemmaer i møte med formelle og uformelle spilleregler i et stort konsern', in Kvande, E. and Rasmussen, B. (eds.) Arbeidslivets klemmer. Bergen: Fagbokforlaget.

Halrynjo, S. and Lyng, S. (2009) 'Preferences, constraints or schemes of devotion?', The British Journal of Sociology 60(2): 321-343.

Hochschild, A. R. (1997) The Time Bind. New York: Henry Holt.

Hyman, J., Scholarios, D. and Baldry, C. (2005) 'Getting on or getting by? Employee flexibility and coping strategies for home and work', Work, Employment and Society 19(4): 705-725.

Håpnes, T. and Rasmussen, B. (2008) 'Postbyråkratiske organisasjoner - et inkluderende arbeidsliv?' Tidsskrift for Velferdsforskning 10(1): 34-49.

Johansen, B. (2007) 'Fleksibilitet - en utfordrer til mødres deltidsarbeid?', in Kvande, E. and Rasmussen, B. (eds.) Arbeidslivets klemmer. Bergen: Fagbokforlaget.

Kitterød, H. R. (2009) 'Vaskehjelp vanligst blant høystatusgrupper', Samfunnsspeilet 5-6, $58-63$.

Kitterød, H. R. (2007a) 'Fremdeles et to-sporet foreldreskap?', in Kvande, E. and Rasmussen, B. (eds.) Arbeidslivets klemmer. Bergen: Fagbokforlaget.

Kitterød, H. R. (2007b) 'Far jobber nesten alltid mest. Arbeidstid blant par av foreldre', in Kvande, E. and Rasmussen, B. (eds.) Arbeidslivets klemmer. Bergen: Fagbokforlaget.

Kitterød, H. R. (2002) 'Mother's housework and childcare: Growing similarities or stable inequalities?’ Acta Sociologica 45(2): 127-149.

Kitterød, H. R. and Pettersen, S. (2002) 'Store endringer i småbarnsforeldres dagligliv', Samfunnsspeilet 16(4-5): 14-22.

Kunda, G. and Ailon-Souday, G. (2004) 'Managers, markets, and ideologies. Design and devotion revisited', in Ackroyd, S., Batt, R., Thompson, P. and Tolbert, P. S. (eds.) The Oxford Handbook of Work and Organization. Oxford: Oxford University Press.

Kvande, E. (2009) 'Work/Life Balance for Fathers in Globalized Knowledge Work. Some insights from the Norwegian context', Gender, Work and Organization 16(1): 58-72.

Kvande, E. and Rasmussen, B. 'Innledning', in Kvande, E. and Rasmussen, B. (eds.) Arbeidslivets klemmer. Bergen: Fagbokforlaget.

McDonald, P., Brown, K. and Bradley, L. (2005) 'Explanations for the provision-utilisation gap in work-life policy', Women in Management Review 20(1): 37-55.

Perrons, D., Fagan, C., McDowell, L., Ray, K. and Ward, K. (2007) Gender Divisions and Working Time in the New Economy. Changing Patterns of Work, Care and Public Policy in Europe and North America. Cheltenham: Edward Elgar. 
Rasmussen, B. (2004) 'Between endless needs and limited resources', Gender, Work \& Organization 11(4): 506-526.

Reisch, L. A. (2001) 'Time and wealth', Time \& Society 10(2/3): 367-385.

Roberts, E. (2008) 'Time and work-life balance: The roles of "temporal customization" and "life temporality", Gender, Work and Organization 15(5): 430-454.

Rousseau, D. (1995) Psychological Contracts in Organizations. Thousand Oaks: Sage.

Sabelis, I, Nencel, L., Knights, D. and Odih, P. (2008) 'Editorial: Questioning the construction of 'balance': A time perspective on gender and organization', Gender, Work and Organization 15(5): 423-429.

Sennett, R. (1998) The Corrosion of Character. New York/London: W. W. Norton \& Company.

Skrede, K. (1986) 'Gifte kvinner i arbeidslivet', in Alldén, L. et al. (ed.) Det norske samfunn. Oslo: Gyldendal.

Van der Lippe, T. (2007) 'Dutch workers and time pressure: household and workplace characteristics', Work, Employment and Society 21(4): 693-711.

Watts, J. H. (2009) “"Allowed into a man's world”. Meanings of work-life balance: Perspectives of women civil engineers as "minority" workers in construction', Gender, Work and Organization 16(1): 37-58. 